\title{
Sr isotopic evidence on the spilitic degradation of the Deccan basalt
}

\author{
K V SUBBARAO \\ Department of Earth Sciences, Indian Institute of Technology, Mumbai (Bombay) 400 076, India. \\ email: subbu@geos.iitb.ernet.in
}

\begin{abstract}
Similar Sr isotopic ratios $(\sim 0.7055)$ for the tholeiite-spilite flow unit and the associated mineral phases, of Bombay (Deccan Traps) provide a direct evidence for the spilitic degradation of tholeiite. In contrast, a dramatic increase in the rare earth elements (REE) from basalt to spilite is rather puzzling as rare earths are considered to be relatively immobile. The geochemistry thus suggests that the process of spilitization is due to the reaction with a complex fluid having identical Sr-isotopic composition as that of the basaltic magma-thereby masking the details of the mixing process.
\end{abstract}

\section{Introduction}

An unusual occurrence of tholeities grading into spilites in the Bhoiwada section of Bombay Island (Deccan basalt) was first described by Sukheswala $(1953,1960)$ who invoked a hydromagmatic model to explain such an association (Sukheswala 1974). Concurrently, Vallence (1974) proposed a secondary low-grade alteration model based on the presence of chemically similar relict clinopyroxenes in both basalt and spilite. While studying the Bhoiwada sequence, Hellman and Henderson (1977) showed for the first time that rare earth elements (REE) are mobile during spilitization, which is indeed a very significant observation. Hence the method of Sr isotopic fingerprinting of the whole rock and mineral components has been used, for the first time, for a better understanding of the process of spilite formation in the Bombay Island.

\section{Bhoiwada section of Bombay}

The $30 \mathrm{~m}$-thick Bhoiwada section (figure $1(\mathrm{a})$ ) is divided into three zones: tholeiite, transitional (spilitetholeiite) and pillowed and non-pillowed spilite (figure 1(b)). The dark compact tholeiitic basalt (at the top) is usually aphyric with intergranular clinopy- roxenes (Ca 36) and anhedral magnetite, occasionally with plagioclase micro-phenocrysts (An 63). The lower green albitized pillowed basalt (spilite) contains clinopyroxene (Ca 32), dusty albite (An 10), K-feldspar, prehenite and laumontite as groundmass minerals, with relatively unaltered magnetite and amygdales with chlorite and zeolite. This rock also shows distinct relict quench textures. The green rock grades upward into a transitional zone of spilite-tholeiite which is fine grained, intergranular with clouded plagioclase (An 83), clinopyroxene (Ca 30), and subordinate secondary minerals (table 1 , figures 2 and 3 ).

\section{Geochemistry}

The spilite is enriched in $\mathrm{Na}, \mathrm{K}, \mathrm{La}, \mathrm{Ce}, \mathrm{Sm}$ and $\mathrm{Eu}$ relative to basalt, and the transitional type lies between the two. While the spilite is ol-hy normative, the basalt is distinctly qtz-normative. A decrease in normative diopside in spilite is observed due to lower concentrations of $\mathrm{CaO}$ (table 1). These changes are quite consistent and follow the geochemical principles of spilitization, i.e., as a secondary process (Vallence 1969).

As pointed out by earlier workers (Hellman and Henderson 1974; Subbarao et al 1979), the marked increase of $\mathrm{RE}$ elements in the Bhoiwada suite of

Keywords. Spilites; Deccan basalt; Sr isotopes. 
(a)

BOMBAY ISLAND, INDIA

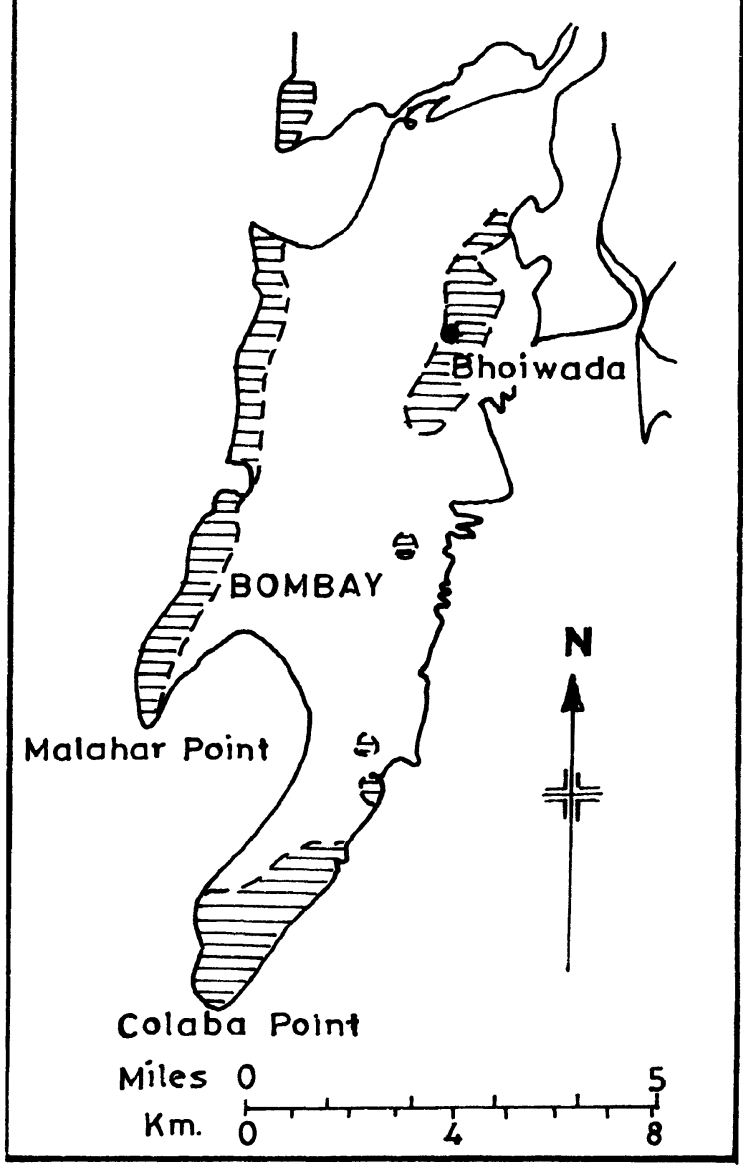

(b) BHOIWADA SECTION

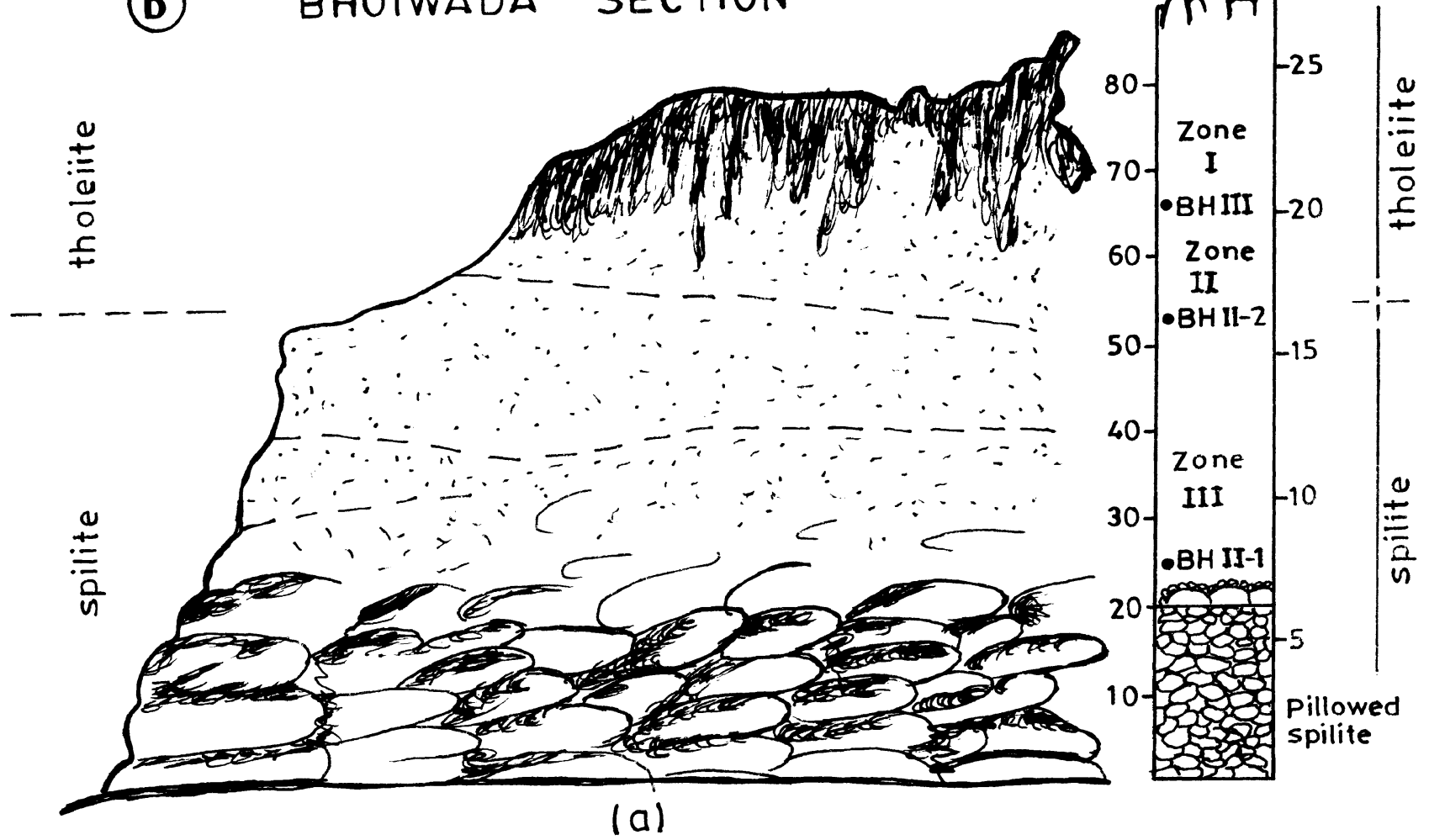

Figure 1(a). Location of Bhoiwada spilite-basalt section, Bombay island (Deccan Traps). Shaded areas represent basalt exposures; (b). Schematic section at Bhoiwada showing different zones and location of samples included in this study (zone I: sample BH III basalt; Zone II: sample BH II-2 spilite-basalt transitional rock; Zone III: sample BH II-1 spilite). 
Table 1. Representative rock and mineral analyses from the Bhoiwada basalt-spilite sequence.

\begin{tabular}{|c|c|c|c|c|c|c|c|c|c|}
\hline \multirow[b]{2}{*}{ Oxides } & \multicolumn{3}{|c|}{ Zone I: Basalt } & \multicolumn{3}{|c|}{ Zone II: Basalt-Spilite Transition } & \multicolumn{3}{|c|}{ Zone III: Spilite } \\
\hline & BH III-2 & BH III-1F & BH III-1Px & BH II-2 & BH II- $2 \mathrm{~F}$ & BH II-2Px & BH II-1 & BH II-1F & BH II-1Px \\
\hline $\mathrm{SiO}_{2}$ & 50.73 & 53.33 & 51.62 & 50.14 & 47.39 & 50.09 & 50.53 & 67.68 & 49.64 \\
\hline $\mathrm{Al}_{2} \mathrm{O}_{3}$ & 13.85 & 29.33 & 1.94 & 13.18 & 32.79 & 1.69 & 13.18 & 21.20 & 2.34 \\
\hline $\mathrm{TiO}_{2}$ & 1.11 & & 0.42 & 1.11 & & 0.60 & 1.04 & & 0.65 \\
\hline $\mathrm{FeO}$ & 8.21 & $1.22^{+}$ & $11.32^{+}$ & 7.54 & $0.64^{+}$ & $18.45^{+}$ & 7.98 & $0.35^{+}$ & $17.2^{+}$ \\
\hline $\mathrm{Fe}_{2} \mathrm{O}_{3}$ & 3.64 & & & 4.38 & & & 3.31 & & \\
\hline $\mathrm{MgO}$ & 6.99 & 0.10 & 15.93 & 6.60 & 0.17 & 13.50 & 7.19 & & 13.85 \\
\hline $\mathrm{CaO}$ & 11.36 & 12.87 & 17.54 & 11.36 & 17.12 & 14.81 & 8.66 & 1.71 & 15.25 \\
\hline $\mathrm{Na}_{2} \mathrm{O}$ & 2.73 & 3.99 & 0.19 & 2.64 & 1.90 & 0.24 & 3.58 & 10.44 & 0.22 \\
\hline $\mathrm{K}_{2} \mathrm{O}$ & 0.64 & 0.16 & & 0.64 & 0.06 & & 1.50 & 0.05 & \\
\hline $\mathrm{MnO}$ & 0.19 & & 0.32 & 0.15 & & 0.42 & 0.19 & & 0.38 \\
\hline $\mathrm{P}_{2} \mathrm{O}_{5}$ & 0.14 & & & 0.16 & & & 0.14 & & \\
\hline Moisture & 0.81 & & & 0.99 & & & 0.86 & & \\
\hline L.O.I & 0.39 & & & 1.21 & & & 2.60 & & \\
\hline $\mathrm{Mg}^{*}$ & 57.89 & & 76.63 & 56.34 & & 63.03 & 59.74 & & 65.23 \\
\hline $\mathrm{Rb}(\mathrm{ppm})$ & 12.70 & & & 12.70 & & & 44 & & \\
\hline $\mathrm{Sr}$ & 192 & & & 195 & & & 634 & & \\
\hline $\mathrm{Ba}$ & 140 & & & 183 & & & 676 & & \\
\hline $\mathrm{Zr}$ & 69 & & & 69 & & & 58 & & \\
\hline $\mathrm{Y}$ & 25 & & & 25 & & & 21 & & \\
\hline $\mathrm{La}$ & 10.30 & & & 13.53 & & & 31.50 & & \\
\hline $\mathrm{Ce}$ & 18 & & & 26.17 & & & 74.70 & & \\
\hline $\mathrm{Sm}$ & 3.04 & & & 2.81 & & & 7.06 & & \\
\hline $\mathrm{Eu}$ & 0.93 & & & 1.02 & & & 2.38 & & \\
\hline $\mathrm{Yb}$ & 3.81 & & & 2.77 & & & 3.06 & & \\
\hline \multicolumn{10}{|c|}{ CIPW Norm } \\
\hline $\mathrm{Q}$ & 4.88 & & & 5.73 & & & & & \\
\hline Or & 3.79 & & & 3.79 & & & 9.11 & & \\
\hline $\mathrm{Ab}$ & 23.1 & & & 22.34 & & & 31.13 & & \\
\hline An & 23.65 & & & 22.23 & & & 15.9 & & \\
\hline Di & 22.38 & & & 23.26 & & & 22.23 & & \\
\hline Hy & 7.04 & & & 5.65 & & & 3.43 & & \\
\hline $\mathrm{Ol}$ & & & & & & & 10.91 & & \\
\hline Mt & & & & & & & 4.93 & & \\
\hline $\mathrm{Hm}$ & 12.76 & & & 12.76 & & & & & \\
\hline $\mathrm{Il}$ & 0.4 & & & 0.32 & & & 2.03 & & \\
\hline $\operatorname{Tn}$ & 2.2 & & & 2.31 & & & & & \\
\hline Ap & 0.33 & & & 0.38 & & & 0.34 & & \\
\hline $\mathrm{Cc}$ & & & & & & & & & \\
\hline \multicolumn{10}{|c|}{ Plagioclase } \\
\hline $\mathrm{Ca}$ & & 63.50 & & & 83 & & & 8.30 & \\
\hline $\mathrm{Na}$ & & 35.60 & & & 16.70 & & & 91.50 & \\
\hline $\mathrm{K}$ & & 0.90 & & & 0.30 & & & 0.30 & \\
\hline \multicolumn{10}{|c|}{ Pyroxene } \\
\hline $\mathrm{Ca}$ & & & 36.10 & & & 30.80 & & & 31.80 \\
\hline $\mathrm{Mg}$ & & & 45.70 & & & 39.10 & & & 40.20 \\
\hline $\mathrm{Fe}$ & & & 18.20 & & & 30 & & & 28 \\
\hline
\end{tabular}

- BH III-2 = Basalt; BH II-2 = Spilite-basalt transitional type; BH II-1 = Spilite; F = Felspar; Px = Pyroxene (this study).

- Major elements Ba, Zr and Y: Inductively Coupled Plasma Atomic Emission Spectrometry (ICPAES) at the Royal Holloway, University of London (Thompson \& Walsh 1981).

- REE: INAA at BARC Mumbai.

- Rb \& Sr: Isotope dilution at the University of British Columbia, Vancouver.

- Mineral Analyses: Electron microprobe (Macquaria University, North Ryde, Australia).

- Mg*: $100^{*} \mathrm{MgO} /\left(\mathrm{MgO}+\left(0.85^{*} \mathrm{FeO}\right)\right.$. The $\mathrm{Mg}$-number is calculated assuming $15 \%$ of the $\mathrm{Fe}$ is $\mathrm{Fe}_{2} \mathrm{O}_{3}$ following Cox $(1980)$.

+ All the Fe is expressed as FeO.

basalt-spilite undermines the utility as a petrogenetic indicator (figure 4; this study). On the contrary, however, the basalts and zeolite facies metabasalts from the Troodos massif and Carlsberg Ridge (basalt- spilite) display similar REE patterns (Smewing and Potts 1976; Subbarao et al 1979), unlike the basaltspilite suite of the Deccan province. The reasons for this diverse chemical behaviour of REEs are not clear. 


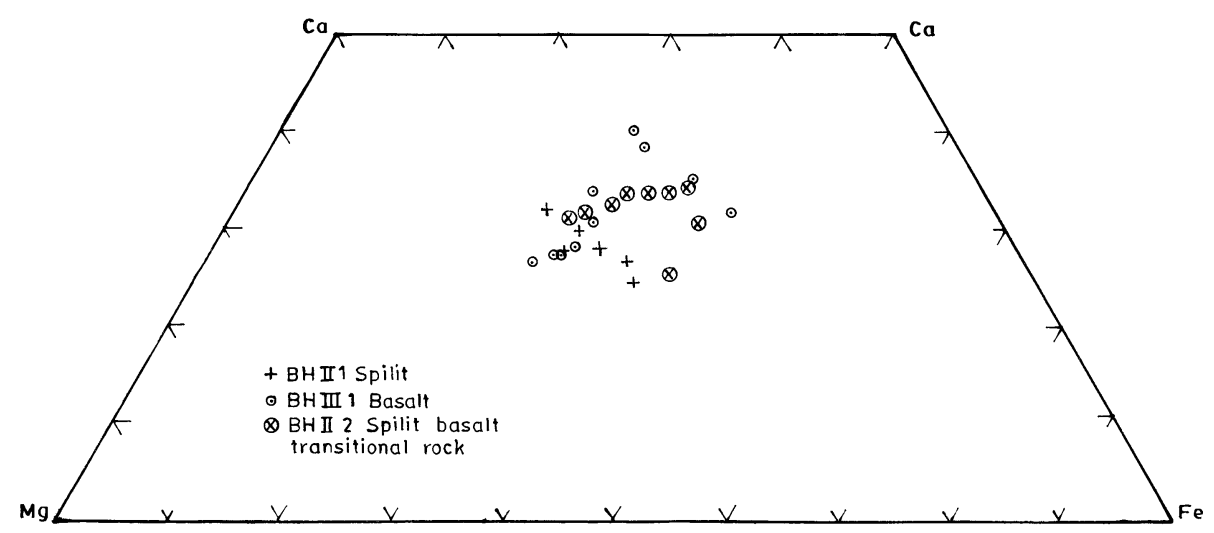

Figure 2. Pyroxene compositional plots (Ca-Mg-Fe diagram) for spilite-basalt sequence.

\section{Sr isotopic composition}

In this paper Sr isotopic composition and concentrations of $\mathrm{Sr}$ and $\mathrm{Rb}$ for the basalt, transitional rock and spilite, and the associated minerals ( $\mathrm{Pl}, \mathrm{Cpx})$ are reported to trace the ancestry of the spilite (table 2).

The age corrected $\left({ }^{87} \mathrm{Sr} /{ }^{86} \mathrm{Sr}\right)_{i}$ and $\mathrm{Rb} / \mathrm{Sr}$ ratios of the basalt, transitional rock and spilite are nearly identical (0.7055, 0.7056, 0.7056; 0.066, 0.065, 0.069; table 2). Interestingly, the minerals ( $\mathrm{Pl}$ and $\mathrm{Cpx})$ from all the three rock types have similar $87 / 86$ ratios as their respective host rocks (see table 2 for details). These results suggest that (a) both minerals and the respective host rocks are in equilibrium despite low-degrees of alteration metamorphism, and

(b) the isotopically similar basalt-spilite association represents a single isochronous flow unit.

\section{Discussion}

The observed variations in the mineralogy (albite in spilite and An rich plagioclase in basalt; chlorite, zeolites, prehenite) and major element geochemistry in the Bombay basalt-spilite association are largely due

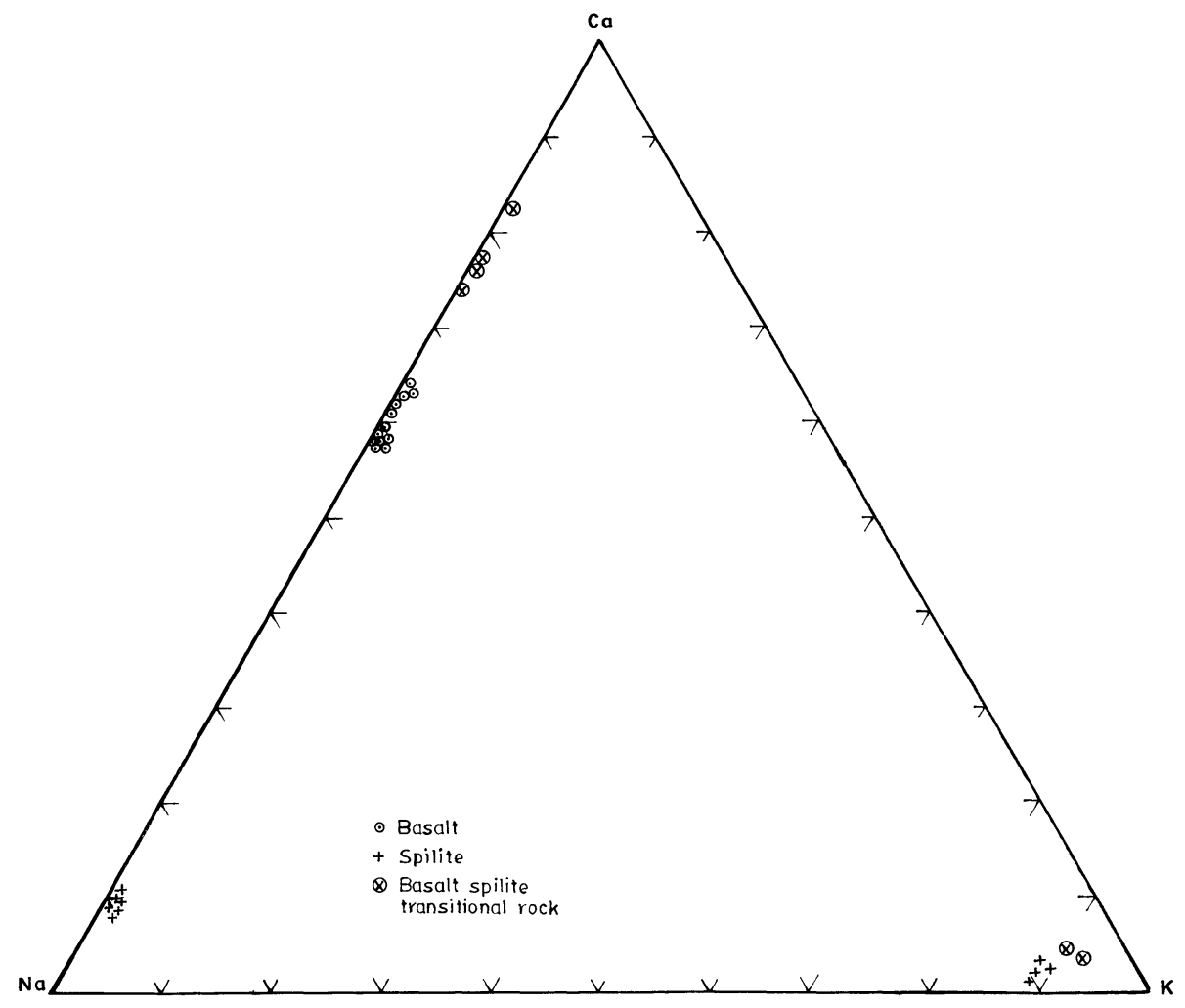

Figure 3. Variation in feldspar compositional data (Ca-Na-K diagram) from spilite-basalt sequence. Note the presence of Kfeldspars in the spilite and transitional rocks. 


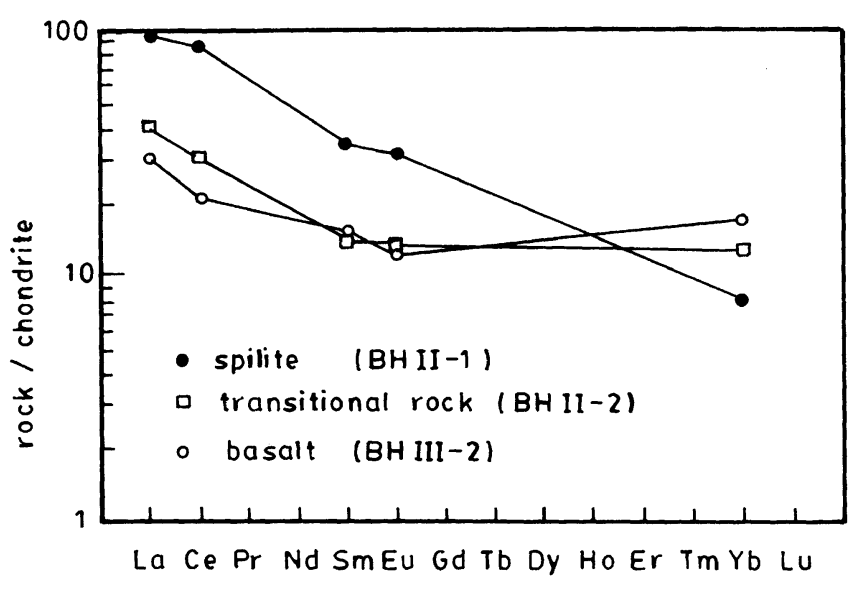

Figure 4. Chondrite normalized REE patterns (see table 1 for data).

to secondary reaction process. Interestingly the pyroxene display limited variation and rather remained unchanged in the basalt-spilite sequence (figure 2). This indeed is a very valuable signature to trace the ancestry of spilites (Vallence 1974).

\subsection{Alteration}

It is clearly evident from the petrography (sericitization) and mineralogy (chlorite, prehenite, calcite) that the spilite and spilite-basalt transitional rock suffered different degrees of alteration, while the basalt remained nearly fresh or least altered. In terms of the "Alteration-Index (A.I)" of Sloman (1987; see figure 5), the Bhoiwada rocks fall approximately into three groups, i.e., A.I. :1-2 (basalts), 3-4 (basalt-spilite transitional rocks, spilites), 5-6 (spilites) (1= least altered, $6=$ highly altered associated with high degree of sericitization). Figure 5 shows that $\mathrm{SiO}_{2}$ and $\mathrm{CaO}$ decrease from basalt $(\mathrm{A} . \mathrm{I}=1-2)$ to spilite $(\mathrm{A} . \mathrm{I}=5-6)$ indicating an increase in secondary minerals; where as increase of $\mathrm{Na}_{2} \mathrm{O}, \mathrm{K}_{2} \mathrm{O}, \mathrm{Ba}$ and $\mathrm{Rb}$ reflects the change from the An-rich to Ab-rich plagioclase and also the presence of K-feldspars. Marked increase in Sr with rising A.I., is perhaps reflected in the presence of laumontite ( $\mathrm{Sr}$ can proxy for $\mathrm{Ca}$ ). As expected, the immobile elements (Ti, Zr, Y) remained unaffected by the alteration process. However, the presence of similar Sr isotopic composition for the basalt and spilite is rather unusual and uncommon, and strongly contrasts with Sloman's observations on the Triassic spilites of Italy (basalt: $\sim 0.7040$, spilite: 0.7060 ).

\subsection{Sr isotopes}

Sr isotopic similarity between spilite and basalt and associated mineral phases-pl and cpx confirms the ancestry of the spilites (i.e., tholeiite) through secondary degradation scheme. If this were to be due to hydromagmatic process, the isotopic ratios ought to have been different. Despite compositional adjustments in spilitization, the Bombay suite permits a still unique opportunity to examine such adjustments (in particular, the mobility of REE) and also establishes the usefulness of isotopic finger printing to get an insight into the magmatic systems as well as the pathways of secondary processes.

\subsection{Nature of the fluids}

Field and fossil evidences indicate shallow marine or brackish water environment for the Bombay eruptions (Sukheswala 1974). Thus the process of low-temperature spilitization involves ionic exchange between solid rock and alkaline rich marine fluids with adjustments in chemistry in both phases. It is likely that the alkaline saline conditions could have been achieved in the early part of the secondary adjustments due to an increase in $\mathrm{pH}$ with base leaching. The hydrolysis of basalt results in residues impoverished in $\mathrm{Ca}$, alkalies and $\mathrm{Si}$ as seen in the interstitial chloritic material of the Bhoiwada spilites. In places, chlorite is also associated with other secondary hydrous minerals

Table 2. Sr isotopic and Sr and Rb isotope dilution data.

\begin{tabular}{lllcccc}
\hline \multicolumn{2}{c}{ Sample no. } & \multicolumn{1}{c}{ Name } & Sr $(\mathrm{ppm})$ & $\mathrm{Rb}(\mathrm{ppm})$ & $\mathrm{Rb} / \mathrm{Sr}$ & ${ }^{87} \mathrm{Rb} /{ }^{86} \mathrm{Sr}$ \\
\hline Zone I & BH III-1 & Basalt & 192 & 12.7 & 0.066 & 0.192 \\
& BH III-1F & Feldspar & 337 & 3.1 & 0.009 & 0.026 \\
\multirow{2}{*}{ Zone II } & BH III-1Px & Pyroxene & 36.8 & 11.1 & 0.302 & 0.873 \\
& BH II-2 & Spilite-Basalt & 195 & 12.7 & 0.065 & 0.189 \\
& & Transition & & & & 0.7055 \\
& BH II-2F & Feldspar & 192 & 1.3 & 0.007 & 0.021 \\
\multirow{2}{*}{ Zone III } & BH II-2Px & Pyroxene & 33.7 & 6.6 & 0.195 & 0.565 \\
& BH II-1 & Spilite & 634 & 43.7 & 0.069 & 0.199 \\
& BH II-1F & Feldspar & 935 & 50.3 & 0.054 & 0.156 \\
& BH I- 2Px & Pyroxene & 100 & 8 & 0.08 & 0.7056 \\
\hline
\end{tabular}

- Isotopic data are reported relative to standard values measured at the University of British Columbia: $\left({ }^{87} \mathrm{Sr} /{ }^{86} \mathrm{Sr}\right)=0.70800$ for

E \& A Sr and 0.71022 for NBS 987 Sr.

- Isotopic fractionation correction ${ }^{87} \mathrm{Sr} /{ }^{86} \mathrm{Sr}=0.1194$.

- Total procedural blanks are $<100$ picograms for Sr and $<20$ picograms for Rb.

- Uncertainties on $\mathrm{Sr}$ and $\mathrm{Rb}$ abundances: $<0.5 \%$ and $<1 \%$. 


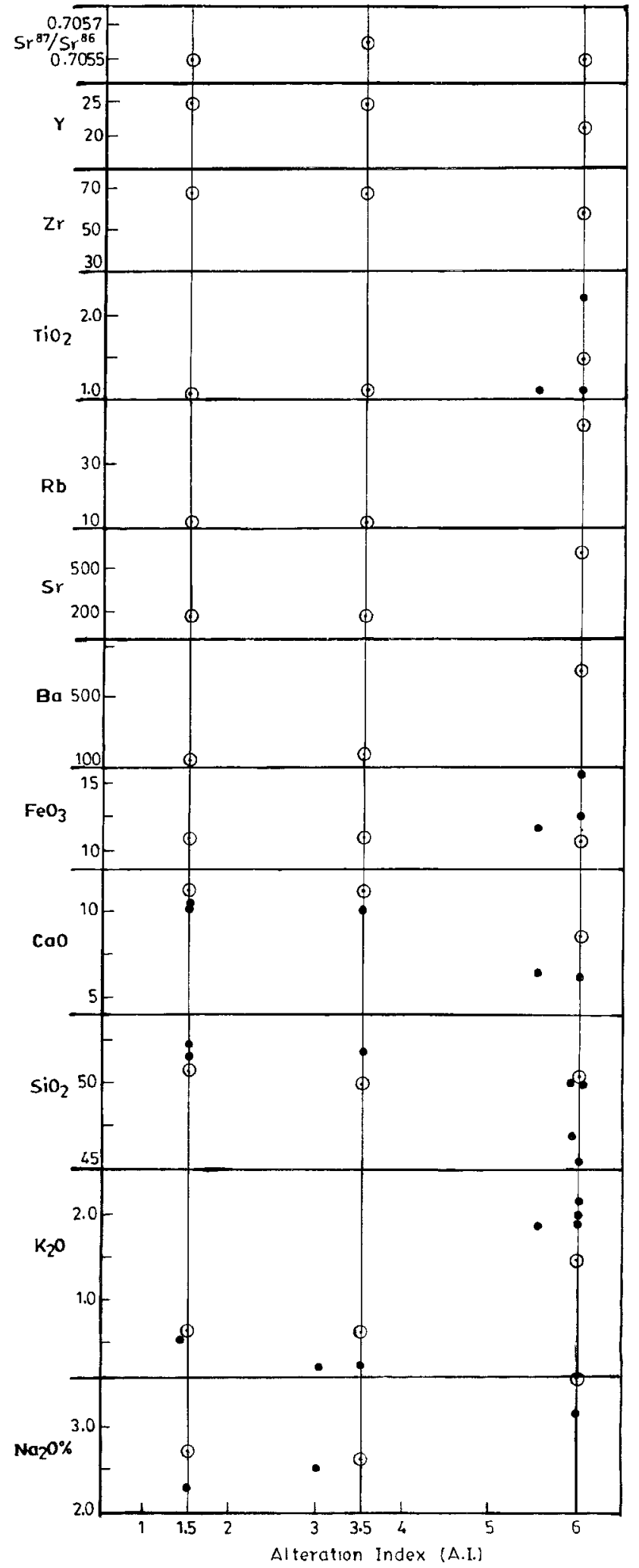

Figure 5. Variation of selected elements with "Alteration Index (I.D)". Open circle with dot represents analyses from this study (see table 1 for data). Solid dot represents analyses from the literature (Sukheswala 1974; Vallence 1974).

such as laumontite, prehnite, calcite and quartz, which perhaps represent the products of subsequent reaction between chlorite and fluid (Vallence 1974).
The important point to be considered at this stage is the absence of any change in Sr-isotopic composition between the basalt and spilite as well as their mineral phases- $\mathrm{Pl}$ and $\mathrm{Cpx}$. Based on the field and chemical evidences, we are justified in assuming sea water as the principal fluid that is responsible for spilitization. If so, the Sr-isotopic composition of Tertiary sea water $(\sim 0.708$, Burke et al 1982) should have been reflected in the spilitized basalt. From the available data, it thus appears that the fluid and magma have nearly identical Sr-isotopic composition and therefore not picking up a mixing or equivalent process. This might suggest that the fluid is of a more complex or unexpected origin unlike originally assumed.

The second puzzling problem relates to the dramatic increase of REE in the spilite, while the $\mathrm{Sr}$ isotopic composition in the entire basalt-spilite sequence remained nearly constant. Earlier, Menzies et al (1993) demonstrated that "extremely high water/rock ratios $\left(>10^{4}\right)$ are required to promote the exchange of REE between basaltic rocks and sea water...". However, the mineralogical data and $\mathrm{Sr}$ isotopic composition negate the role of high-temperatures in the case of the Bhoiwada spilite association. It is also unlikely that the secondary hydrothermal fluids (zeolitization) would have had any effect, as the zeolites are formed around $200^{\circ} \mathrm{C}$ (Jeffrey et al 1988) with extremely poor REE concentrations (James and Walsh, in press; and personal discussions).

\section{Summary}

New Sr isotopic and elemental data for the unique sequence of basalt grading into albite-chlorite spilite from the Bombay island (Deccan Traps) provide new clues to the problems of spilitization.

- Nearly identical ${ }^{87} \mathrm{Sr} /{ }^{86} \mathrm{Sr}(\sim 0.7055)$ for the basaltspilite and associated pyroxene and plagioclase indicates perfect equilibrium condition; and points out either the inert nature of the minerals (in particular pyroxene) or the presence of a complex fluid.

- REE are preferentially mobilized during spilitization. This is rather unexpected in such a low temperature hydrothermal system.

- Reaction between interstitial residues (i.e. chlorite) and fluid could easily result in the formation of secondary minerals such as laumontite, prehnite, calcite and quartz.

\section{Acknowledgements}

I am grateful to Richard Armstrong for his valuable assistance with $\mathrm{Sr}$ isotopic analysis; and to Keith Cox, Gunter Faure, Paul Henderson, S Viswanathan and 
Martin Menzies for discussions and critical comments on an earlier version of this manuscript. I am deeply indebted to Nick Walsh for generously supporting my visit to the UK, providing invaluable help in the ICP laboratory (Royal Holloway University of London) and a congenial atmosphere for the preparation of Deccan manuscripts; and for a critical review of this manuscript.

\section{References}

Burke W H, Denison R E, Hetherington E A, Koepnick R B, Nelson H F and Otto J B 1982 Variation of seawater ${ }^{87} \mathrm{Sr} /$ ${ }^{86}$ Sr throughout Phanerozoic time; Geology 10 516-519

Cox K G 1980 A model for flood basalt volcanism; J. Petrol. 21 629-650

Hellman P L and Henderson P 1977 Are rare earth elements mobile during spilitization?; Nature 267 38-40

James S and Walsh J N Zeolites from the Deccan Basalts; Mem. Geol. Soc. India (West volume) 43 (in press)

Jeffrey K L, Henderson P, Subbarao K V and Walsh J N 1988; The zeolites of the Deccan basalt-a study of their distribution; Mem. Geol. Soc. India 10 151-162

Menzies M A, Long A, Ingram G, Tatnell M and Janecky D 1993 MORB peridotite sea water interaction experimental constraints on the behaviour of trace elements, ${ }^{87} \mathrm{Sr} /{ }^{86} \mathrm{Sr}$ and
${ }^{143} \mathrm{Nd} /{ }^{144} \mathrm{Nd}$ ratios; In Magmatic processes and Plate Tectonics. (eds) H M Prichard et al; Geol. Soc. Special Publication $\mathbf{7 6}$ pp. 309-322

Sloman L E 1987 Middle Triassic magmatism in the Dolomites, Nothern Italy; Unpublished D. Phil Thesis University of Oxford

Smewing J D and Potts P J 1976 Rare-earth Contrib Mineral Petrol abundances in basalts and metabasalts from the Troodos Massif, Cyprus; Contrib. Mineral. Petrol. 57 245-258

Subbarao K V, Reddy V V, Reddy G R and Sukheswala R N 1979 Rare earth element geochemistry of basalt-spilite association of Bombay and Carlsberg Ridge-a preliminary study; J . Geol. Soc. India 20 517-519

Sukheswala R N 1953 Notes on the field occurrence and petrography of the rocks of the Bombay Island, Bombay; Trans. Mining Geol. Met. Inst. India 50 101-126

Sukheswala R N 1960 Albitized basalts of Bombay and the associated intertrappeans: A preliminary survey; Indian Science Congress Association, Bombay (abstract)

Sukheswala R N 1974 Gradation of tholeiitic Deccan basalt into spilite, Bombay, India. In Spilites and Spilitic Rock. (eds) G C Amstutz (Heidelberg: Springer-Verlag) pp. 229-250

Thompson M and Walsh J N 1989 Handbook of inductively coupled plasma spectrometry; (London: Chapman and Hall)

Vallence T G 1969 Spilites again: Some consequences of the degradation of basalts; Proc. Linn. Soc. N.S.W. 85 8-51

Vallence T G 1974 Spilitic degradation of a tholeiitic basalt; $J$. Petrol. 15 79-9 